\title{
The production of effective power from a vehicle engine waste heat
}

\begin{abstract}
The paper presents an overview of selected items of literature related to the possible use of the heat from a vehicle engine exhaust that is normally released to the environment. Systems of new standards, still on the testing stage not currently in use have been analyzed. The disadvantages such as large mass and high costs of the steam systems have been indicated. Thermo-generators, in turn, are characterized by low electric power per unit weight. In the last chapter the authors discuss the accumulation of heat in order to reduce the engine warm-up time.
\end{abstract}

Key words: vehicle engine use of waste heat

\section{Możliwości zamiany strumieni ciepła odpadowego silników pojazdów na moc efektywną}

W artykule przedstawiono przegląd wybranych pozycji literatury na temat możliwości wykorzystania ciepła odprowadzanego z silnika do otoczenia. Wymieniono głównie nowe, niestosowane seryjnie, ale obecnie projaktowane i badane układy. Wskazano na niekorzystne cechy, takie jak duża masa i duże koszty układów parowych. Termogeneratory z kolei charakteryzują się mała moca elektryczna na jednostkę masy. W ostatnim rozdziale wspomniano o akumulacji ciepła w celu skrócenia procesu nagrzewania silnika.

Słowa kluczowe: wykorzystanie ciepła odpadowego silnika samochodowego

\section{Introduction}

Costly and massive waste heat recuperation systems have not yet been used in automotive vehicles. Currently, tests of steam piston engines, steam turbines and electric cells are underway.

The largest sources for the production of effective energy are as follows in the efficiency order: engines exhaust gases, engine coolant and lubricant.

\section{The use of the cycle of the vapor of water solution}

In heavy-duty vehicles the exhaust gases downstream the turbocharger reach a temperature of approximately $450{ }^{\circ} \mathrm{C}[4]$.

The most advanced works on the prototypes are related to the Rankine cycle using vapor of a water solution of 2-methylpyridine or ethanol for the turbo generator or a generator driven by a steam machine [4] (Fig. 1).

The steam pressures in this cycle amount to $4 \mathrm{MPa}$. The evaporation takes place at $250{ }^{\circ} \mathrm{C}$ and further condensation is possible owing to the circulation of coolant. This takes place at $100^{\circ} \mathrm{C}$.

The efficiency of the Rankine cycle at the said parameters is 0.18 .

Choking of the flow of exhaust gases by fitting a heater in the exhaust pipes may result in a $1 \%$ drop in the engine efficiency.

The placement of the heater downstream the aftertreatment system is not the best solution as the increased load on the cooling system triggered by the condensation of steam will result in an increased power consumption of the radiator fan.

Rather advantageous seems the fact that steam is generated in the recirculated exhaust gas cooler rather than

\section{Wstęp}

W pojazdach drogowych kosztowne i o dużej masie układy utylizacji ciepła nie były dotychczas stosowane. Obecnie prowadzi się próby prototypów układów z parowymi silnikami tłokowymi, turbinami parowymi i ogniwami elektrycznymi.

Największym źródłem energii do produkcji energii użytecznej są spaliny silnika, następnie ciecz chłodząca, a potem olej.

\section{Wykorzystanie obiegów pary roztworu wodnego}

W ciężkich samochodach użytkowych spaliny silnika za turbosprężarką mają temperaturę około $450{ }^{\circ} \mathrm{C}$ [4].

Najbardziej zaawansowane prace nad prototypami dotyczą wykorzystania obiegu Rankine'a z użyciem pary roztworu wodnego 2-metylopirydyny albo alkoholu etylowego do napędu turbogeneratora, lub generatora napędzanego maszyną parową [4] (rys. 1).

Ciśnienia pary w tym obiegu wynoszą $4 \mathrm{MPa}$. Parowanie zachodzi wówczas przy $250^{\circ} \mathrm{C}$, a skraplanie umożliwia obieg cieczy chłodzącej silnik. Następuje ono przy $100^{\circ} \mathrm{C}$.

Sprawność obiegu Rankine’a przy wspomnianych parametrach wynosi 0,18 .

Dławienie przepływu spalin, przez zamontowanie w ich trakcie wylotowym kotła, może spowodować około jednoprocentowy spadek sprawności silnika.

Umieszczenie kotła za układem oczyszczania spalin nie jest najlepszym rozwiązaniem, gdyż wzrost obciążenia układu chłodzenia, spowodowany skraplaniem pary, spowoduje wzrost mocy pobieranej przez wentylator chłodnicy.

Dosyć korzystna wydaje się produkcja pary w chłodnicy recyrkulacji spalin, a nie tylko w trakcie wylotowym spalin, ponieważ spaliny muszą być chłodzone (rys. 2). 


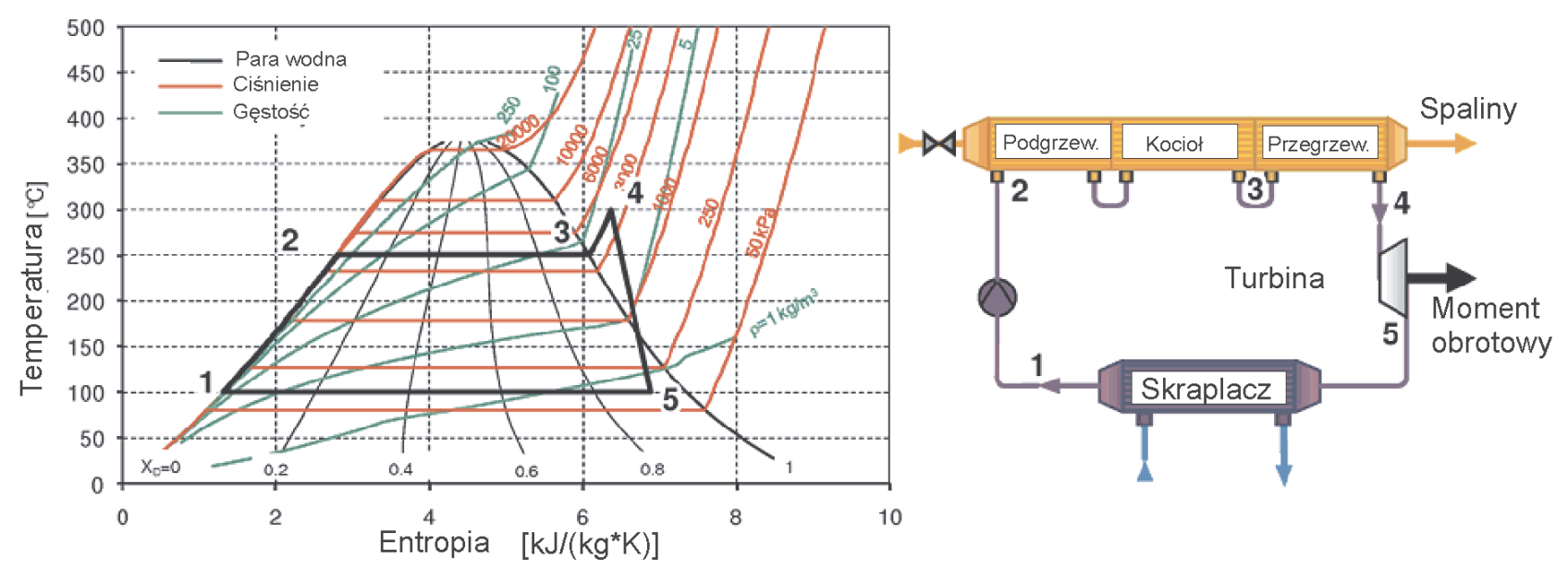

Fig. 1. Rankine thermodynamic cycle and the schematics of the system for its realization [4]

Rys. 1. Obieg termodynamiczny Rankine'a i schemat uktadu do jego realizacji [4]

exclusively in the exhaust pipes because the exhaust gases must bee cooled down (Fig. 2).

The steam cycles using the exhaust gases and the coolant have been described in [3]. The works have been carried out for BMW.

In a system known as 'turbosteamer' (Fig. 3) a piston steam machine 3 drives a shaft through a cycle transmission. The steam of the water solution works in two independent circulations: high and low temperature ones. The steam for both circulations is formed in the steam generator 1 . In the high temperature circulation it is overheated in the overheater 2 . The steam, after the work is done in the piston engine 3 , is condensed in the high temperature (5) and low temperature (4) condensers.
Obiegi parowe wykorzystujące spaliny i ciecz chłodzącą zostały opisane w [3]. Prowadzono prace na zlecenie firmy BMW.

W układzie o nazwie ,turbosteamer” (rys. 3) tłokowa maszyna parowa 3 napędza wał napędowy samochodu przez przekładnię obiegową. Para roztworu wodnego pracuje w dwu niezależnych obiegach: wysokotemperaturowym i niskotemperaturowym. Para dla obu obiegów powstaje w wytwornicy 1 . W obiegu wysokotemperaturowym jest przegrzewana w przegrzewaczu 2. Para po wykonaniu pracy w tłokowym silniku 3 jest skraplana w skraplaczu wysokotemperaturowym 5 i niskotemperaturowym 4 .

\section{Wykorzystanie ciepła spalin do produkcji energii elektrycznej}

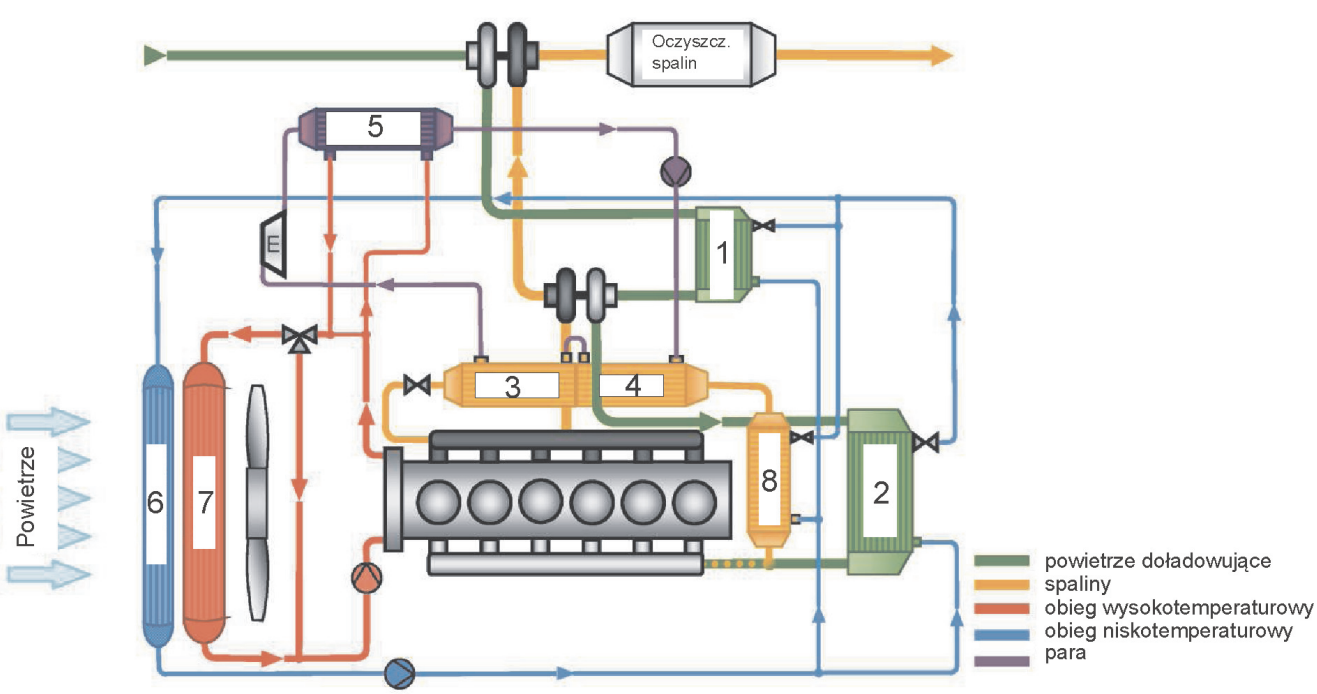

Fig. 2. Thermal systems of a heavy duty vehicle engine (prototype): 1 - high pressure intercooler, 2 - low pressure intercooler, 3 - steam tank, 4 - heater, 5 - condenser, 6 - low temperature circulation cooler, 7 - high temperature circulation cooler, 8 - recirculated exhaust gas cooler [4]

Rys. 2. Układy cieplne silnika ciężkiego samochodu użytkowego (prototyp): 1 - wysokociśnieniowa chłodnica powietrza doładowujacego, 2 - niskociśnieniowa chłodnica powietrza doładowania, 3 - zbiornik pary, 4-kociot,

5 -skraplacz, 6 - chtodnica obiegu niskotemperaturowego, 7 - chłodnica obiegu wysokotemperaturowego, 8 - chłodnica spalin recyrkulacji [4]
Wykorzystanie dużej ilości ciepła odprowadzanego do otoczenia do produkcji energii elektrycznej często było celem badań naukowych.

Szczególnie obecnie przy zastosowaniu hybrydowych układów napędowych pojazdów, czy dużej mocy odbiorników energii elektrycznej w samochodach, produkcja energii elektrycznej z ciepła jest pożądana.

Uzyskanie przepływu prądu w obwodzie zamkniętym polega na umieszczeniu w 2 różnych metali w różnych temperaturach. Jest to zjawisko odkryte przez 


\section{The use of the exhaust gas heat in the production of electrical energy}

The use of a high amount of heat released to the atmosphere for the production of electrical energy is frequently an objective in scientific research.

The production of electrical energy is particularly needed at present when hybrid powertrains or high power consumption energy receivers are used in vehicles.

The obtainment of current in a closed circuit consists in placing two different metals in different temperatures. This is a phenomenon discovered by Seebeck and Peltier. Such sources are referred to as mono-generators. The amount of generated energy depends on the differences of the temperature of the metals.

The stream of heat that can be converted into electrical power is expressed by the formula (1) [5]:

$$
\dot{\mathrm{Q}}=\gamma \cdot\left(\mathrm{T}_{\mathrm{H}}-\mathrm{T}_{\mathrm{C}}\right) \cdot \mathrm{I}-\frac{1}{2} \cdot \mathrm{R}_{\mathrm{TG}} \cdot \mathrm{I}^{2}
$$

where: $\dot{\mathrm{Q}}$ - stream of heat, $\mathrm{T}_{\mathrm{H}}$ - higher metal temperature, $\mathrm{T}_{\mathrm{C}}$ - lower metal temperature, $\gamma$ - the Seeber-Peltier effect coefficient, I - current intensity, $\mathrm{R}_{\mathrm{TG}}$ - thermo-generator internal resistance.

The idea of placing of the thermo-generators in the exhaust systems has been shown in Fig. 4.

Because current research results [4] indicate a 3\% exhaust gas heat usage when driving with the speed of 140 $\mathrm{km} / \mathrm{h}$, considering the high investment costs the above described solution is not sufficiently practical for vehicles in city traffic.

\section{The reduction of the engine warm-up time}

The effective power (being the difference of the stream of heat fed with the fuel and air) and the loss capacity can grow when these losses are reduced.

An increase in the engine efficiency in the warm-up time consists in the reduction of this time, thus a reduction of the engine friction losses. This is not a direct conversion of thermal power to the effective power but indirectly it does grow. The reduction of the warm-up time is realized through several methods.

The first method is software control of the cooling system by blocking the circulation in the warm-up period. The stopping of the pump additionally positively influences the balance of engine power by boosting the mechanical efficiency in this time $[6,7]$.
Seebecka i Peltiera. Takie źródła nazywane są termogeneratorami. Ilość wytworzonej energii zależy od różnicy temperatur metali.

Strumień ciepła, jaki można zamienić na moc elektryczną przedstawia wzór (1) [5], gdzie: $\dot{\mathrm{Q}}$ - strumień ciepła, $\mathrm{T}_{\mathrm{H}}-$ wyższa temperatura umieszczenia metalu, $\mathrm{T}_{\mathrm{C}}-$ niższa temperatura umieszczenia metalu, $\gamma$ - współczynnik efektu Seebera-Peltiera, I - natężenie prądu, $\mathrm{R}_{\mathrm{TG}}$ - rezystancja wewnętrzna termogeneratora.

Ideę rozmieszczenia termogeneratorów w układzie wylotu spalin pokazano na rys. 4 .

Ponieważ obecne wyniki badań [4] wskazują na 3\% wykorzystania ciepła spalin, przy jeździe z prędkością 140 $\mathrm{km} / \mathrm{h}$, przy znacznych kosztach inwestycyjnych, opisany sposób utylizacji ciepła jest na razie nieprzydatny w samochodach osobowych w ruchu miejskim.

\section{Skrócenie okresu rozgrzewania silnika}

Moc użyteczna będąca różnicą strumienia ciepła doprowadzonego z paliwem i powietrzem oraz mocy strat może wzrosnąć, gdy zmniejszą się te straty.

Zwiększenie sprawności silnika w okresie rozgrzewania silnika polega na skróceniu procesu nagrzewania i wobec tego zmniejszeniu strat tarcia silnika. Nie jest to bezpośrednia zamiana odprowadzanej mocy cieplnej na moc efektywną, ale pośrednio zwiększa tę moc. Skrócenie procesu nagrzewania jest realizowane kilkoma metodami.

Pierwsza metoda to programowe sterowanie układem chłodzenia silnika przez zatrzymywanie obiegu cieczy w okresie nagrzewania. Zatrzymanie pracy pompy wpływa dodatkowo korzystnie na bilans mocy silnika przez zwiększenie w okresie zatrzymania sprawności mechanicznej $[6,7]$.

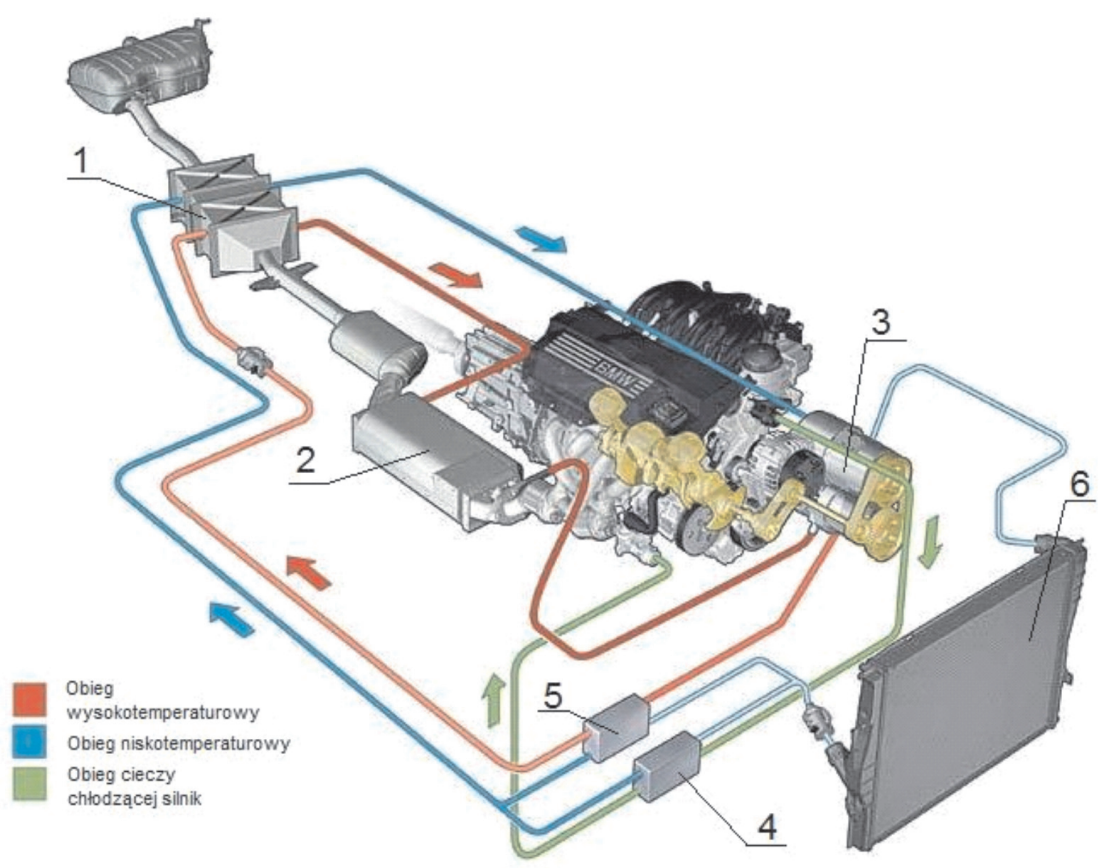

Fig. 3. The steam system known as 'turbosteamer' [3] Rys. 3. Układ parowy ,, turbosteamer” [3] 
The other method is heating up the coolant or lubricant with the heat accumulated in the coolant during last engine operation [2]. Alternatively, heat can be accumulated in PCM substances that in the range of temperatures that are typical of engine operation can change their phases.

The third way is direct heating of the coolant with hot exhaust gases when the engine warms up [1].

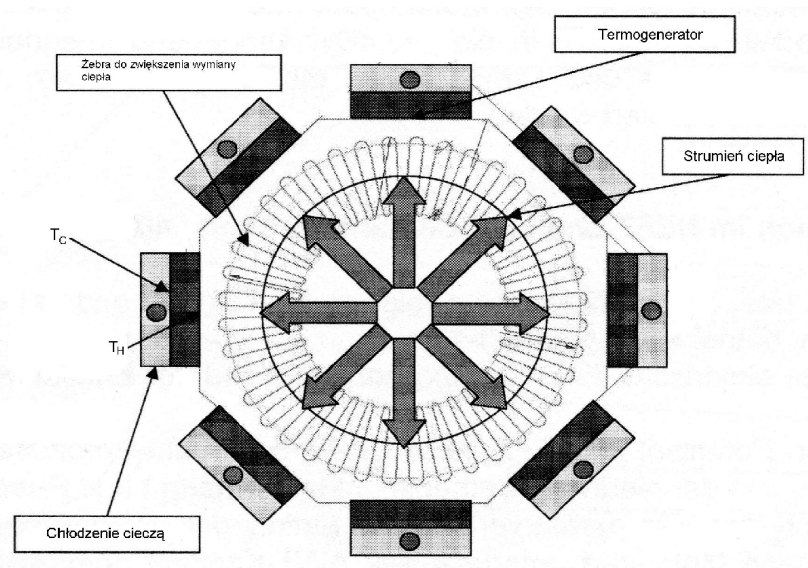

Fig. 4. Schematics of the thermo-generators in the exhaust system [5] Rys. 4. Schemat konstrukcji termogeneratorów w uktadzie wylotu spalin [5]

\section{Conclusions}

The selected solutions of boosting of the effective power presented in this paper are nothing but an attempt to increase the engine efficiency.

A better use of the released heat stream is forecasted as an alternative to a modification of the engine internal design.

The works carried out are twofold. For heavy-duty vehicles the state of thermal balance and the conversion of the heat stream into effective power are more important.

For passenger vehicles used in cities the periods of operation during warm-up are very important (burdened with high losses).

The reduction of the warm-up time through an introduction of software control of the cooling system should bring the expected increase in the vehicle powertrain efficiency.

\section{Nomenclature/Skróty i oznaczenia}

PCM Phase changing materials/substancje zmieniajace faze

$\dot{\mathrm{Q}} \quad$ stream of heat/strumień ciepła

$\gamma$ the Seeber-Peltier effect coefficient/współczynnik efektu Seebera-Peltiera

I current/prąd

RTG thermo-generator internal resistance/rezystancja wewnętrzna termogeneratora

Zbigniew Kneba, DSc., DEng. - adiunkt in the Faculty of Mechanical Engineering at Gdańsk University of Technology.

Dr inż. Zbigniew Kneba - adiunkt na Wydziale Mechanicznym Politechniki Gdańskiej.

e-mail: zkneba@sunrise.pg.gda.pl
Druga metoda to podgrzanie cieczy chłodzącej silnika lub oleju ciepłem zakumulowanym w cieczy chłodzącej podczas poprzedniej jazdy [2]. Alternatywnie można akumulować ciepło w substancjach typu PCM, które w zakresie używanych w układach chłodzenia temperatur zmieniają stan skupienia.

Trzeci sposób to bezpośrednie podgrzewanie spalinami cieczy chłodzącej w okresie rozgrzewania silnika [1].

\section{Podsumowanie}

Opisane wybrane rozwiązania zwiększenia mocy użytecznej silnika sprowadzają się do zwiększenia jego sprawności.

Planuje się większe wykorzystanie strumienia ciepła odprowadzanego do atmosfery jako alternatywne do zmian konstrukcji wewnętrznej silnika.

Prace są prowadzone dwutorowo. Dla pojazdów użytkowych ważniejszy jest stan równowagi cieplnej i zamiana strumieni odprowadzanego ciepła na moc użyteczną.

Z kolei dla samochodów osobowych eksploatowanych $\mathrm{w}$ miastach istotne są okresy pracy podczas rozgrzewania obarczone dużymi stratami.

Skrócenie okresu rozgrzewania przez wprowadzenie programowego sterowania pracą układu chłodzenia powinno przynieść spodziewane zwiększenie sprawności napędu samochodu.

Paper reviewed

\section{Bibliography/Literatura}

[1] Bals R., Pfeifer E., Lewe P.: Direkte Abgaswarmenutzung am Ottomotor Wärmemanagement der Kraftfahrzeuges VI, Expertverlag Essen 2008, s. 50-68.

[2] Brzeżański M.: Emisja toksycznych składników spalin w fazie nagrzewania się silnika o zapłonie iskrowym z zastosowaniem akumulatora ciepła, monografia nr 326, seria Mechanika, Kraków 2007.

[3] Clemens H., Collisi J., Hoetger M.: Das Amovis Abwärmenutzungkoncept: 15 Jahre praktische Erfarung mit Mikrodampfprocessen. Wärmemanagement der Kraftfahrzeuges VI, Expertverlag 2008, s. 32-49.

[4] Freyman R.: Der Turbosteamer: Ein System zur Kraft-WärmeKopplung im Automobil. MTZ 5/2008.

[5] Kitte J., Tietze T., Jansch D., Bals R.: Modellirung und Simulation in Dymola/Modelica als Basis zur Entwicklung innovativer Wärmemanagementstrategien. Wärmemanagement der Kraftfahrzeuges VI, Expertverlag 2008, s. 252-280.

[6] Kneba Z.: New generation cooling systems for car engines, BALTTEHMAŠ: Progressivnye Tehnologii, Mašiny i Mehanizmy v Mašinostroenii: sbornik naučnyh trudov Meždunarodnoj Baltijskoj Associacii Mašinostroitelej, Kaliningrad 2006 red. L.I. Poliŝuk. Kaliningrad: Kaliningradskij Gosudarstvennyj Tehničeskij Universitet.

[7] Kneba Z.: Możliwości zmniejszenia mocy potrzebnej do napędu pompy cieczy chłodzącej silnika samochodowego, Journal of KONES: Powertrain and Transport, Vol. 15, nr 3 (2008), s. 239-244. 